
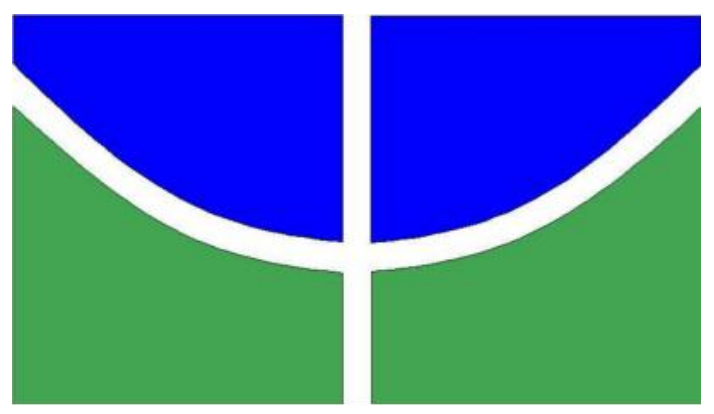

UNIVERSIDADE DE BRASÍLIA

Faculdade de Agronomia e Medicina Veterinária

Programa de Pós-Graduação em Saúde Animal

\title{
OCORRÊNCIA DE HEMOPARASITAS EM TARTARUGAS-DA-AMAZÔNIA (Podocnemis expansa) E CÁGADOS-DE-BARBICHA (Phrynops geoffroanus) ORIUNDAS DA FUNDAÇÃO ZOOLÓGICO DE BRASÍLIA, DISTRITO FEDERAL, BRASIL.
}

LOURDES MARINA BEZERRA PESSOA

DISSERTAÇÃO DE MESTRADO EM SAÚDE ANIMAL 

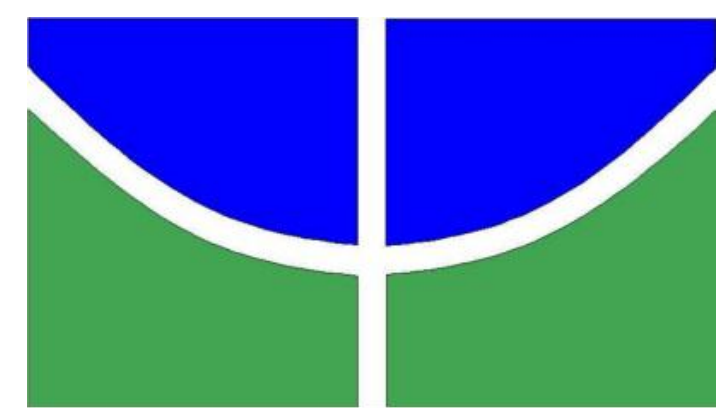

UNIVERSIDADE DE BRASÍLIA

Faculdade de Agronomia e Medicina Veterinária

Programa de Pós-Graduação em Saúde Animal

OCORRÊNCIA DE HEMOPARASITAS EM TARTARUGAS-DAAMAZÔNIA (Podocnemis expansa) E CÁGADOS-DE-BARBICHA (Phrynops geoffroanus) ORIUNDAS DA FUNDAÇÃO ZOOLÓGICO DE BRASÍLIA, DISTRITO FEDERAL, BRASIL.

LOURDES MARINA BEZERRA PESSOA

ORIENTADOR: GIANE REGINA PALUDO

DISSERTAÇÃO DE MESTRADO EM SAÚDE ANIMAL

PUBLICAÇÃO: 113/2015

BRASÍLIA/DF 
UNIVERSIDADE DE BRASILIA

OCORRÉNCIA DE HEMOPARASITAS EM TARTARUGAS-DA-AMAZÔNIA (PODOCNEMIS EXPANSA) E CAGADOS-DE-BARBICHA (PHRYNOPS GEOFFROANUS) ORIUNDAS DA FUNDAÇĀO ZOOLÓGICO DE BRASÍLIA, DISTRITO FEDERAL, BRASIL.

LOURDES MARINA BEZERRA PESSOA

DISSERTAÇĀO DE MESTRADO SUBMETIDA AO PROGRAMA DE PÓS-GRADUAÇÄO EM SAÚDE ANIMAL, COMO PARTE DOS REQUISITOS NECESSÁRIOS A OBTENÇÃO DO GRAU DE MESTRE EM SAÚDE ANIMAL.

APROVADA POR:

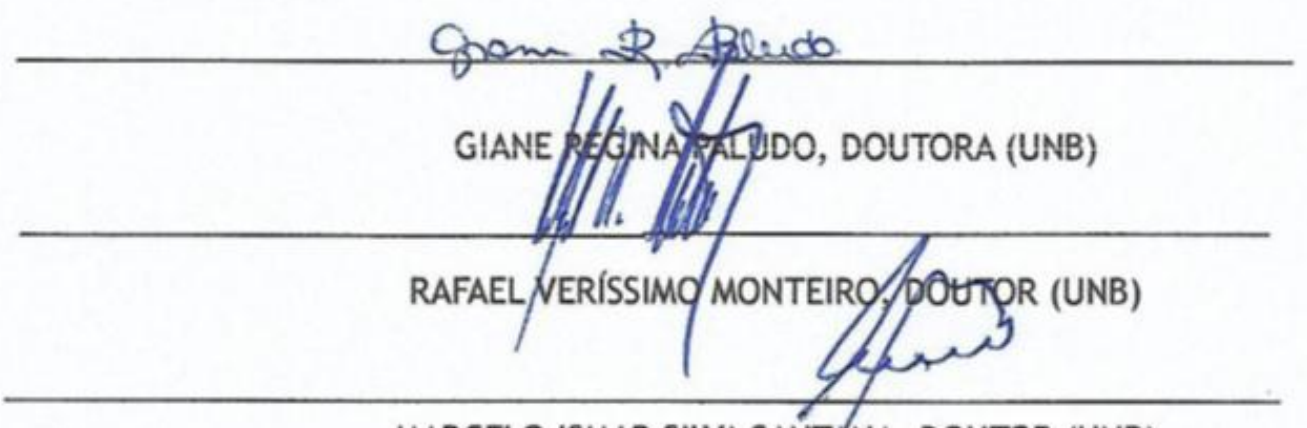

MARCELO ISMAR SILVA SANTANA, DOUTOR (UNB)

BRASÍLIA/DF, 10 DE JULHO DE 2015. 


\section{BRASÍLIA/DF, 10 DE JULHO DE 2015 REFERÊNCIA BIBLIOGRÁFICA E CATALOGAÇÃO}

PESSOA, L. M. B. Ocorrência de hemoparasitas em Tartarugas-da-Amazônia (Podocnemis expansa) e cágados-de-barbicha (Phrynops geoffroanus) oriundas da Fundação Zoológico de Brasília, Distrito Federal, Brasil. Brasília: Faculdade de Agronomia e Medicina Veterinária, Universidade de Brasíla, 2015, 47p. Dissertação de Mestrado.

Documento formal, autorizando reprodução desta dissertação de Mestrado para empréstimo ou comercialização, exclusivamente para fins acadêmicos; foi passado pelo autor à Universidade de Brasília e acha-se arquivado na secretaria do Programa. O autor reserva para si os outros direitos autorais, de publicação. Nenhuma parte desta dissertação de mestrado pode ser reproduzida sem a autorização por escrito do autor. Citações são estimuladas, desde que citada a fonte.

FICHA CATALOGRÁFICA

Pessoa, Lourdes Marina Bezerra

Ocorrência de hemoparasitas em Tartarugas-da-Amazônia (Podocnemis expansa) e cágados-de-barbicha (Phrynops geoffroanus) oriundas da Fundação Zoológico de Brasília, Distrito Federal, Brasil./Lourdes Marina Bezerra Pessoa

Orientação de Giane Regina Paludo

Brasília, 2015. 47p

Dissertação de mestrado (M) - Universidade de Brasília/ Faculdade de Agronomia e Veterinária, 2015 
Dedico este trabalho aos meus pais, Ricardo e Filomena, pelo exemplo de vida, por sempre acreditarem nos meus sonhos e ajudarem tanto a realizá-los. A todos os animais que desde muito tempo fazem parte do meu dia-a-dia, ensinando-me da sua maneira, sobre respeito, gratidão, simplicidade, compaixão e amor, e por serem minha fonte inspiradora e grandes motivadores a seguir minha carreira. Especialmente, dedico aos queridos cágados que fizeram parte desse projeto e que me provaram, mais uma vez, que nesse mundo não existe vida maior ou menor, inferior ou superior, e que cada ser vivo tem sua importância nesse universo. 


\section{AGRADECIMENTOS}

A Deus, em primeiro lugar, por tudo que tem me concedido.

Aos meus pais Ricardo e Filomena por todo o amor, carinho, atenção e cuidados que sempre me deram, mesmo eu estando a quilômetros de distância. Por me ensinarem que a família é a base de tudo e que o amor tudo transforma. Por serem meu porto seguro!

Aos meus irmãos, Ricardo, Eduardo, Pedro e Helena, por todo o apoio nas minhas decisões, pelas palavras amigas e por sempre acreditarem nos meus sonhos "mais loucos". Amo vocês!

A minha cunhada, Gabriele Matos, por sempre está disposta a ajudar e ser como uma irmã.

Ao meu namorado, Claudio Foleto Marchewicz Junior, conquista inesquecível, pelo carinho, paciência, incentivo, ajuda e companheirismo.

A minha orientadora Profa. Dra. Giane Regina Paludo, pela orientação nesse trabalho, pelos ensinamentos, conselhos e paciência. Muito obrigada pela oportunidade de trabalhar com você e pela confiança depositada.

Ao Prof. Dr. Rafael Veríssimo Monteiro, por ter aberto as portas para mim na Universidade de Brasília, pela confiança depositada e por toda a ajuda durante o planejamento do projeto e deu uma "super força" na análise estatística.

Ao Zoológico de Brasília por ter concedido os animais para a pesquisa, em especial, aos funcionários da instituição que nos receberam com muita atenção, carinho e dedicação ao trabalho. Meu agradecimento especial ao Alberto e a Mariana, por toda dedicação e comprometimento na ajuda da realização das coletas e toda a mobilização da equipe do Zoo para pegar as tartarugas no lago. Jamais esquecerei todo esse esforço e ajuda!

A todos os colegas, amigos, estagiários, alunos, residentes, veterinários e biólogos que me ajudaram durante o processo de coleta e processamento de material, todos sempre com muita atenção, cuidado e preocupação.

A toda equipe do Laboratório de Patologia Clínica Veterinária, pela ajuda na análise das amostras, pela paciência e ensinamentos.

A todos os meus amigos mais íntimos pela paciência, amor e carinho, pelas palavras de incentivo e por se fazerem sempre presente mesmo estando a 
quilômetros de distância.

Aos amigos e familiares que me deram hospedagem em Brasília durante esse período, em especial aos primos Tibério Pinheiro e sua esposa Lina Távora, a prima Luiza Pinheiro, as amigas Laís Marchewicz e Ana Raquel Ferreira. Obrigada por todo carinho e receptividade.

A amiga Nárjara Grossman, pela energia de sua amizade, pelos ensinamentos, pela ajuda nas colheitas a campo, pela companhia e bate-papo durante esses anos.

A amiga e companheira de mestrado, Carol Mota, pela amizade, conselhos, ensinamentos, atenção, companhia e por ter aberto as portas da sua casa para me hospedar.

As amizades conquistadas durantes esses anos, e de muito valor, em especial a minha amiga e conterrânea, Ana Raquel Ferreira, pela amizade, carinho, hospedagem e pela disponibilidade em me ajudar sempre que precisei.

A colega e funcionária do Laboratório de Patologia Clínica e Biologia Molecular, Marcela Scalon, pela atenção e disposição para me ensinar e ajudar nas coletas e análises das amostras.

Ao Prof. Doutor Macelo Isma Silva Santana, por ter aceitado o convite para participa da minha banca de defesa.

Aos docentes, funcionários e colegas do Curso de Pós-Graduação pelo convívio e respeito.

Ao Instituto Lina Galvani, pela confiança e liberação para idas a Brasília para assistir as aulas.

A todos aqueles que de uma forma ou outra auxiliaram para a conclusão desta etapa da minha formação profissional. 
"Prezo insetos mais que aviões. Prezo a velocidade das tartarugas mais que a dos mísseis.

Tenho em mim esse atraso de nascença.

Eu fui aparelhado para gostar de passarinhos. Tenho abundância de ser feliz por isso. Meu quintal é maior do que o mundo." (Manoel de Barros) 


\section{SUMÁRIO}

Página

LISTA DE SÍMBOLOS E ABREVIAÇÕES..................................................... $\mathrm{x}$

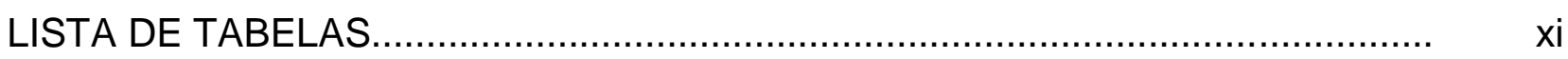

LISTA DE FIGURAS..................................................................................

RESUMO

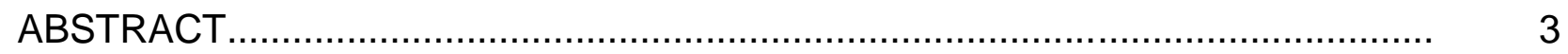

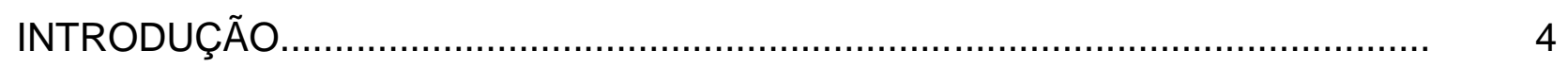

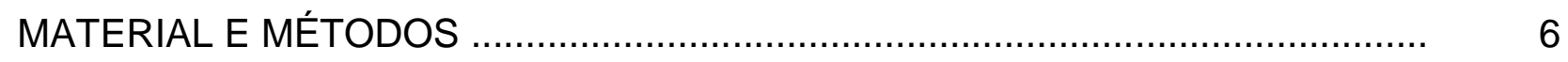

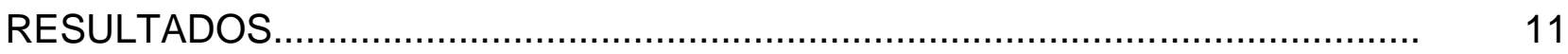

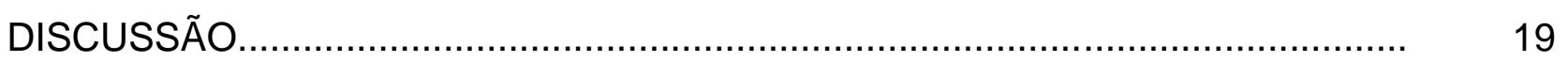

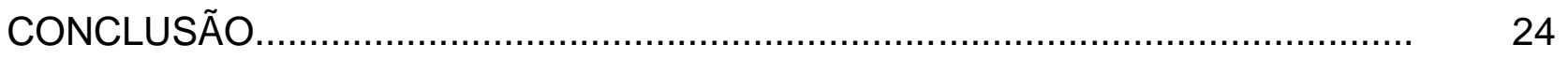

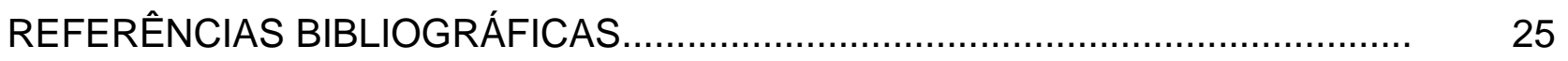




\section{LISTA DE SÍMBOLOS E ABREVIAÇÕES}

$\% \quad$ Porcentagem

$\mu \mathrm{L} \quad$ Microlitros

ALT Alanina aminotransferase

Ca Cálcio

CK Creatina quinase

dl Decilitros

DNA Ácido desoxirribonucleico

dNTP Trifosfatos de desoxirribonicleosídeos

FA Fosfatase alcalina

g/dl Gramas por decilitro

$\mathrm{Meq} / \mathrm{L} \quad$ Miliequivalente por litro

mg Miligramas

$\mathrm{mg} / \mathrm{dL} \quad$ Miligramas por decilitro

$\mathrm{MgCl}$ Cloreto de magnésio

$\mathrm{mL} \quad$ Mililitros

$\mathrm{mM} \quad$ Mili Molar

C Graus Celcius

$\mathrm{pb} \quad$ Pares de base

PCR Polimerase Chain Reaction (Reação em cadeia de polimerase)

pmol Picomoles

PPT Proteínas plasmáticas totais

PT Proteína total

sp Espécie

$\mathrm{UI} / \mathrm{L} \quad$ Unidades internacionais por litro 


\section{LISTA DE TABELAS}

Página

Tabela 1. Sequência de oligonucleotídeos, tamanho dos produtos de 8 amplificação e referência bibliográfica das reações de PCR utilizadas.

Tabela 2. Número de cágados positivos nos testes realizados no estudo.

Tabela 3. Número de animais positivos para hemoparasitas detectados em cada método de diagnóstico utilizado (Microscopia óptica M.O. e PCR) distribuídas por espécie e sexo.

Tabela 4. Valores médios e desvio padrão dos parâmetros hematológicos e bioquímicos dos animais positivos e negativos para infecção por hemogregarinas na PCR nas duas espécies estudadas $(n=99)$.

Tabela 5. Valores médios e desvio padrão dos parâmetros hematológicos e bioquímicos dos animais positivos e negativos para infecção por Hepatozoon sp. na PCR nas duas espécies estudadas $(n=99)$.

Tabela 6. Valores médios e desvio padrão dos parâmetros hematológicos

e bioquímicos dos cágados positivos e negativos para a infecção por hemogregarinas na PCR na espécie Phrynops geoffroanus $(\mathrm{n}=77)$. 


\section{LISTA DE FIGURAS}

Página

Figura 1. Eritrócitos de um cágado de barbicha (Phrynops geoffroanus) do 12 estudo onde se observa a presença de hemoprotozoários, salientando que esses animais foram negativos para os testes de PCR utilizados no estudo.

Figura 2. Eritrócito de tartaruga-da-Amazônia (Podocnemis expansa) com presença de um gametócito de hemoparasita (seta).

Figura 3. Eritrócito de $P$. expansa infectado por dois hemoparasitas no mesmo eritrócito (seta).

Figura 4. Resultado de PCR para detecção de hemoparasitos utilizando os oligonucleotídeos para detecção de hemograrinas. 1 - Marcador de peso molecular (100pb); 2 - controle negativo (água); 3 controle positivo; 5, 6, 7, 10, 12,13, 14 e 15 - animais negativos ; 4,8,9 e 11 - animais positivos para o grupo das hemogregarinas. Gel de agarose a 1,5\% (p/v) com brometo de etídeo a 0,01\% (p/v).

Figura 5. Resultado de PCR para detecção de hemoparasitos utilizando os oligonucleotídeos para detecção de Hepatozoon spp.: PCR "HEP”, 1 - Marcador de peso molecular (100pb); 2 - controle negativo (água); 3 - controle positivo; 11 e 12 - animais positivos para Hepatozoon spp. ; 4,5,6,7,8,9,10 e 13 - animais negativos. Gel de agarose a 1,5\% (p/v) com brometo de etídeo a 0,01\% (p/v). 


\section{RESUMO}

O presente estudo teve como objetivo determinar a ocorrência da infecção por hemoparasitas em cágados, por meio da PCR. Utilizaram-se 99 cágados das espécies $P$. expansa e $P$. geoffroanus mantidas na Fundação Zoológico de Brasília. Foram usados dois conjuntos de oligonucleotídeos, sendo o HEMO1/HEMO2 utilizados para detecção de hemogregarinas e o HEPR/HEPF para detecção do gênero Hepatozoon sp. Foi detectada a presença de hemogregaina em 20 amostras estudadas $(n=99)$, onde onze foram positivas para hemogegaina, cinco foram detectados Hepatozoon sp. e quatro foram positivas para ambos os oligonucleotídeos. Observaram-se alterações laboratoriais nos parâmetros de proteínas plasmáticas totais, trombócitos, proteínas séricas totais e globulinas nos animais positivos para hemogregarinas e apenas alterações nos trombócitos nos animais positivos para Hepatozoon sp. em ambas as espécies estudadas.

Palavras chaves: hemoparasitas, cágados, PCR, hemogregarina, Hepatozoon. 


\begin{abstract}
The aim this study was determine the occurrence of infection by hemoparasites in freshwater turtles, through PCR. Samples of 99 freshwater turtles of species $P$. expansa and $P$. geoffroanus of Fundação Zoológico de Brasília. We used two sets of oligonucleotides, being the HEMO1 / HEMO2 used for detection of hemogregarines and HEPR / HEPF for detection of the genus Hepatozoon sp. The presence of hemogregarine was detected in 20 samples analyzed ( $n=99$ ), and eleven samples were positive for hemogregarine, five were Hepatozoon sp. and four were positive for both oligonucleotides. Laboratory abnormalities has been observed in the parameters of total plasma proteins, trombocytes, total serum proteins and globulin in animals positive for hemogregarines and only abnormalities in thrombocytes in positive animals Hepatozoon sp. in both species.
\end{abstract}

Keywords: hemoparasites, freshwater turtles, PCR, hemogregarine, Hepatozoon. 


\section{INTRODUÇÃO}

Os animais silvestres estão expostos a inúmeros agentes infecciosos e parasitários, dentre eles os hemoparasitas, que são transmitidos por vetores hematófagos. Sua presença é considerada um achado acidental em algumas espécies, no entanto, podem provocar doenças como anemia hemolítica. Dentre os hemoprotozoários comuns em répteis estão as hemogregarinas, os tripanossomos e os plamódios (THRALL et al.,2007).

As hemogregarinas são parasitas intraeritrocitários mais comumente observadas em répteis (GARCIA-NAVARRO; PACHALLY, 1994, WOSNIAK et al., 1994). O termo hemogregarina tem sido utilizado, através de décadas, para descrever coletivamente parasitas sanguíneos pertencentes às subordens Eimeriina e Adeleina do Filo Apicomplexa (LEVINE et al., 1980). Historicamente, parasitas sangüíneos de anfíbios, serpentes, tartarugas, lagartos, crocodilianos, aves e mamíferos foram incluídos no gênero Haemogregarina, como resultado da similaridade morfológica de gamontes entre hemogregarinas de diferentes gêneros (DESSER et al., 1995, SMITH, 1996). Espécies de Haemogregarina não podem ser distinguidas de Hepatozoon sp. tendo como base somente a aparência de seus gamontes intraeritrocíticos e merontes hepáticos. A identificação do gênero é também dependente da natureza do desenvolvimento esporogônico no vetor (DESSER et al., 1995).

Os hospedeiros intermediários do gênero Haemogregarina são os vertebrados aquáticos (peixes e répteis), as sanguessugas os hospedeiros definitivos (SIDDALL, DESSER, 1993; SIDDALL,1995; SIDDALL, DESSER, 2001). O ciclo de vida da maioria das Haemogregarinas ainda é desconhecido, mas sabe-se que em quelônios a espécie com o ciclo mais bem conhecido é o da Haemogregarina balli, 
um parasita da tartaruga mordedora (Chelydra serpentina) e da sanguessuga Placobdella ornata (SIDDALL, DESSER, 1991). Outras espécies de Haemogregarina têm sido documentadas em quelônios de todo o mundo e mais recentemente, alguns estudos de prevalência e intensidade de Haemogregarina foram investigadas em cágados da Romênia (MIHALCA et al, 2008), EUA (DAVIS; STERRETT, 2011), da Índia (MOLLA et al, 2013) e do Irã (JAVANBAKHT, SHARIFI, 2014). No Brasil, existem poucos relatos documentados da presença de hemoparasitas do subfilo Aplicomplexa em tartarugas (MUNDIM et al.,1994; LAINSON, NAIFF, 1998; CAMPOS-BRITES, RANTIN, 2004; SOARES et al.,2014; PICELLI et al.,2015). Já o gênero Hepatozoon pode ser encontrado parasitando anfíbios, répteis, aves e mamíferos e, dentre os répteis foram relatados em lagartos, crocodilianos, tartarugas e serpentes (SMITH, 1996). Os principais vetores invertebrados de Hepatozoon são mosquitos, mosquito-palha, moscas tse-tse, triatomíneos, piolhos, pulgas e ácaros (SMITH, 1996). Há, também, relatos de sanguessugas atuando como vetores destes parasitas (PESSOA, CAVALHEIRO, 1969a,b; SMITH, 1996).

A patogenicidade das hemoparasitoses para seus hospedeiros ainda é pouco conhecida. Baixos níveis de parasitismo não parecem afetar a saúde do organismo hospedeiro (CAUDELL et al., 2002), no entanto, em hospedeiros não naturais, pode alcançar proporções significativas em condições de cativeiro, quando não há rígido controle parasitológico, justificando-se a necessidade de um bom diagnóstico para evitar a disseminação da doenças dentro das populações cativas (CAMPBELL, 1996; O’DWYER et al.,2003). Protozoários no sangue podem afetar os répteis, reduzindo a sua capacidade de transporte de oxigênio (CAUDELL et al., 2002).

Pouco se sabe acerca dos efeitos fisiológicos de infecções com hemoparasitas sobre espécies de cágados brasileiros, nem tampouco se estes realmente causam 
uma doença clínica, nem qual sua severidade. No entanto, sabe-se que estes parasitas inevitavelmente competem por energia e nutrientes com o hospedeiro, que consequentemente deve escolher entre a quantidade de energia investida no esforço reprodutivo e a batalha imunológica contra parasitas (MØLLER, 1997). Respostas imunes adaptativas contra parasitas são dispendiosas, manifestadas por reduzida condição corporal e uma defesa comprometida contra as infecções secundárias por parasitas hemosporideos (OLSSON et al., 2005). Co-ocorrência de diferentes espécies de parasitas no mesmo hospedeiro pode alterar as características da história de vida de formas diferentes a partir de efeitos de uma única espécie (MAJLÁTHOVÁ et al., 2010). Os organismos hospedeiros respondem adaptativamente a um parasitismo, alterando determinados traços da história de vida (MINCHELLA, 1985). Relatos tem documentado que os parasitas Haemogregarinidiae influenciaram várias características da história de vida, como condição da massa corporal (AMO et al., 2004), a mortalidade dependendo da idade do hospedeiro (SORCI, 1996), cor, composição de secreções das glândulas femorais (MARTIN et al., 2008) e redução na regeneração caudal após autotomia (OPPLIGER; CLOBERT,1997).

O diagnóstico dessas parasitoses é feito pela técnica do esfregaço sanguíneo (CAMPBELL, 1996; O'DWYER et al., 2003), mas, atualmente, diagnósticos mais modernos incluem a avaliação do sangue pela técnica de reação em cadeia de polimerase (PCR) (WOSNIAK et al., 1994).

Diante disso o presente estudo propôs determinar a ocorrência de hemogregarinas em cágados mantidos na Fundação Zoológico de Brasília, por meio da PCR e as alterações laboratoriais decorrentes destas infecções. 


\section{MATERIAL E MÉTODOS}

Foram utilizados 99 espécimes de cágados, sendo 77 da espécie Phrynops geoffroanus (Cágado-de-barbicha) e 22 Podocnemis expansa (Tartaruga-daAmazônia), de diferentes faixas etárias, machos e fêmeas, pertencentes ao acervo da Fundação Zoológico de Brasília. Os animais foram capturados do recinto de exposição e do lago da instituição, com a utilização de um puçá, sendo imediatamente identificados individualmente por microchips, após realização de exame clinico completo, pesagem e sexagem. Todos os dados foram anotados em fichas individuais. As amostras de sangue foram colhidas por punção do seio occipital, de acordo com a técnica descrita por MARTíNEZ-SILVESTRE et al., 2002, e acondicionadas em dois tubos, um seco e estéril para separação de soro para análise bioquímica, e outro contendo anticoagulante heparina sódica para análise hematológica e molecular. Imediatamente após a colheita foram preparados dois esfregaços sanguíneos, com o sangue de cada animal para pesquisa direta de hemoparasitas. Os esfregaços sanguíneos, preparados no local da colheita, foram secados ao ar e posteriormente fixado e corado, utilizando o corante comercial tipo Romanowsy rápido (Panótico-Instant-Prov NewProv®, Pinhais, Paraná, Brazil). A pesquisa direta de hemoparasitas foi realizada em microscópio óptico COLEMAN N107 em objetiva de 400X. Ressaltamos que as amostras contaminadas por hemolinfa foram descartadas. As análises foram realizadas no Laboratório de Patologia Clínica da Faculdade de Agronomia e Medicina Veterinária da Universidade de Brasília.

As contagens totais de eritrócitos, leucócitos e trombócitos foram feitas em câmara de Neubauer improved®. com uma diluição de 1:200 em solução de Natt e Herrick. A dosagem de hemoglobina $(\mathrm{Hb})$ foi feita pelo método espectrofotométrico 
onde utilizamos $10 \mu \mathrm{l}$ de sangue total com $5 \mathrm{ml}$ do reagente de cor (de acordo com as orientações do fabricante - Labtest $\left.^{\circledR}\right)$. O volume globular(VG) foi determinado pela técnica do micro-hematócrito com a utilização de capilares sem heparina e microcentrífuga (CELM ${ }^{\circledR}$ Mod. MH, Barueri, São Paulo, Brazil), enquanto as proteínas plasmáticas totais (PPT) foram determinadas com o auxílio do refratômetro portátil (Modelo: SZJ-D). O sangue restante foi refrigerado para realização dos estudos de caracterização molecular pela técnica da PCR.

Para avaliação das análises bioquímicas foi separado soro das amostras acondicionadas em tubos sem anticoagulante. Foram utilizados kits bioquímicos específicos $\left(\right.$ Labtest $^{\circledR}$, Lagoa Santa, Minas Gerais, Brazil) seguindo recomendações do fabricante e a leitura foi realizada em um analisador bioquímico semi-automático (Bioplus $^{\circledR}$ Bio2000, Barueri, São Paulo, Brazil) para determinação dos valores séricos de úreia, ácido úrico, cálcio, creatina quinase (CK), aspartato aminotransferase (AST), fosfatase alcalina (FA), fósforo, proteína total (PT), albumina, globulina e glicose.

O DNA das amostras foi extraído a partir de $10 \mu \mathrm{l}$ de sangue para a realização do exame molecular (PCR) com auxílio de kits comerciais (Illustra Blood genomicPrep Mini Spin kit, GE Healthcare®, Piscataway, NJ.), seguindo a metodologia proposta pelo fabricante. Após extração, as amostras foram acondicionadas em freezer $-20^{\circ} \mathrm{C}$ até o momento do uso.

Foram realizados dois tipos de exames moleculares em cada amostra obtida. Após as extrações todas as amostras foram submetidas a PCR para detecção de hemogregarinas, utilizando diferentes conjuntos de oligonucleotídeos (Tabela 1) que detectam regiões do gene $18 \mathrm{~S}$ rRNA, onde o conjunto de oligonucleotídeos HEMO1/HEMO2 pode amplificar gêneros do grupo das hemogregarinas e alguns 
parasitas apicomplexas (Hepatozoon sp., Babesia sp., Theileria sp., Hemolivia sp., Haemogregarina sp.) (PERKINS;KELLER,2001), enquanto o HEPR/HEPF são específicos para amplificar parasitas do gênero Hepatozoon sp. (INOKUMA et al., 2002).

Tabela 1. Sequência de oligonucleotídeos, tamanho dos produtos de amplificação e referência bibliográfica das reações de PCR utilizadas.

\begin{tabular}{cccc} 
Reação/Oligonucleotídeos & Sequência 5'-3' & Tamanho & $\begin{array}{c}\text { Referência } \\
\text { bibliográfica }\end{array}$ \\
\hline Hemogregarinas & & & \\
HEMO1 & TATTGGTTTTAAGAACTAATTTTATGATTG & Perkins e \\
HEMO2 & CTTCTCCTTCCTTTAAGTGATAAGGTTCAC & $1000 \mathrm{pb}$ & Keller, 2001 \\
\hline Hepatozoon sp. & ATACATGAGCAAAATCTCAAC & & \\
\hline HEPF & CTTATTATTCCATGCTGCAG & $652 \mathrm{pb}$ & Inokuma et \\
HEPR & & al., 2002 \\
\hline
\end{tabular}

A reação do mix para a PCR da HEP foi composta de tampão $1 \mathrm{X}$ de $\mathrm{PCR}, 10$ ng de DNA, $\mathrm{MgCl}_{2}$ 1,6 mM, 0,2 mM de cada de oxinucleotídeoh, 0,5 $\mu \mathrm{L}$ de cada oligonucleotídeo (10pmol) e 1 U de Taq DNA polimerase em um volume final de 25 $\mu \mathrm{L}$. O protocolo de amplificação foi composto de uma etapa de desnaturação inicial de $95^{\circ} \mathrm{C}$ por 5 minutos seguida de 40 ciclos de amplificação $\left(95^{\circ} \mathrm{C}\right.$ por 30 segundos, $52^{\circ} \mathrm{C}$ por 30 segundos e $72^{\circ} \mathrm{C}$ por 90 segundos) e extensão final a $72^{\circ} \mathrm{C}$ por 5 minutos, de acordo com o descrito em Inokuma et al., 2002. Para a reação do mix para a PCR da HEMO foi utilizado a composição de tampão $1 \mathrm{X}$ de $\mathrm{PCR}$, 10ng de DNA, $\mathrm{MgCl}_{2} 2 \mathrm{mM}, 0,2 \mathrm{mM}$ de cada de oxinucleotídeoh, $1 \mu \mathrm{L}$ de cada oligonucleotídeo (10pmol) e 1,25 U de Taq DNA polimerase em um volume final de $25 \mu \mathrm{L}$. O protocolo de amplificação foi composto de uma etapa de desnaturação inicial de $94^{\circ} \mathrm{C}$ por 5 minutos seguida de 35 ciclos de amplificação $\left(94^{\circ} \mathrm{C}\right.$ por 1 
minuto, $48^{\circ} \mathrm{C}$ por 1 minuto e $72^{\circ} \mathrm{C}$ por 1 minuto) e extensão final a $72^{\circ} \mathrm{C}$ por 5 minutos, de acordo com o descrito em Perkins e Keller, 2001. Cada reação foi checada para contaminação pelo uso de controles negativos utilizando todos os reagentes exceto o DNA. Todas as reações de amplificação foram realizadas no mesmo aparelho termociclador (Biorad ${ }^{\circledR}$ C1000TM Thermal Cycler, Hercules, CA.).

Os produtos das PCRs foram analisados por eletroforese em gel de agarose corado com brometo de etídio (Vetec, Sigma-Aldrich ${ }^{\circledR}$, St. Louis, MO) e observados sob transiluminador (UV Transilluminator UVP ${ }^{\circledR}$, Upland, CA.) de fluorescência ultravioleta. Um marcador molecular (Invitrogem ${ }^{\circledR}$, Vila Guarani, São Paulo, Brazil.) com intervalos de pesos moleculares de 100pb foi incluído em cada eletroforese como um padrão de comparação de altura das bandas para determinação do tamanho do produto amplificado.

O aparecimento de bandas na altura dos pares de bases esperadas foi considerado o parâmetro para classificar as amostras como positivas. Em todas as PCRs foram utilizados como controle negativo água miliQ (estéril e desprovida de DNA). Como controles positivos, para as PCRs de HEMO e HEP, foram utilizadas amostras de animais da mesma espécie positivos na microscopia óptica e que apresentaram positivos nos teste da PCR padrão e contrateste.

Os métodos experimentais deste projeto foram avaliados e aprovados pelo Comitê de Ética no Uso Animal, CEUA - UNB (UnBDOC No154161/2013) e a captura e a manipulação dos animais foram autorizadas pelo Instituto Chico Mendes de Conservação da Biodiversidade - ICMBio através do Sistema de Autorização e Informação em Biodiversidade - SISBIO (Nº 38444-4).

$\mathrm{Na}$ análise estatística foi testada a hipótese de que as infecções por hemogregarinas identificados por exame molecular (hemogregarina e Hepatozoon 
sp.) eram associados a modificação nos parâmetros de saúde analisados. Para isso foi primeiro criado um modelo misto linear, utilizando as espécies analisadas (Phrynops geoffroanus e Podocnemis expansa) e o recinto de origem (lago e recinto de exposição) como fatores aleatórios e as infecções como fatores fixos, para testar cada uma das variáveis de saúde. Depois as espécies foram separadas e testado um modelo linear para cada espécie em separado, utilizando como fatores fixos, novamente, a infecção por hemoparasitas. Com auxílio do software $\mathrm{R}^{\circledR}$ e o pacote Ime4 para execução das análises, considerando o intervalo de confiança de 95\%. 


\section{RESULTADOS}

Das 99 espéciemes de cágados estudados, 48 eram fêmeas, 48 machos e 3 indeterminados. Deste total, 20,21\% (20/99) foram positivas para presença de hemogregarinas em alguma das PCRs realizadas, sendo que na PCR para hemogregarinas foram observadas 15,15\% (15/99) amostras positivas e na PCR para o gênero Hepatozoon spp. foram encontradas 9,09\% (9/99) cágados positivos. Enquanto que micoscopia óptica tivemos uma ocorrência de $66,67 \%$ dos animais com pesença de hemoparasitas.

Cabe salientar que 5 animais foram positivos somente na PCR para Hepatozoon spp. ou seja, não amplificaram na PCR para hemogregarinas, 11 foram positivos somente para PCR para hemogregarinas e quatro foram positivos nas duas reações utilizadas (Tabela 2). Importante observar que três animais foram negativos no exame direto, mas apresentaram-se positivos no teste para PCR para hemogregarinas, comprovando a sensibilidade dos exames moleculares.

Tabela 2. Número de cágados positivos nos testes realizados no estudo.

\begin{tabular}{ccc}
\hline Método & M.O Positivos (66/99) & Total de Animais Positivos \\
\hline PCR “HEMO” & 8 & 11 \\
PCR “HEP” & 9 & 9 \\
PCR “HEMO” + “HEP” & 4 & 4 \\
TOTAL & 17 & 20 \\
\hline
\end{tabular}

Onde: "HEMO": PCR para o grupo das hemogregarinas; "HEP": PCR para o gênero Hepatozoon spp.; M.O: microscopia óptica

Foram observados hemoparasitas em 50.5\% (50/99) dos animais amostrados e que não foram identificados pelos testes moleculares realizados. $\mathrm{Na}$ análise morfológica estes parasitas apresentaram forma cilíndrica e ocupava posições 
laterais dentro do eritrócito, na presença desse organismo foi observada também um alargamento das células hospedeiras e deslocamento lateral do núcleo (Figura 1).

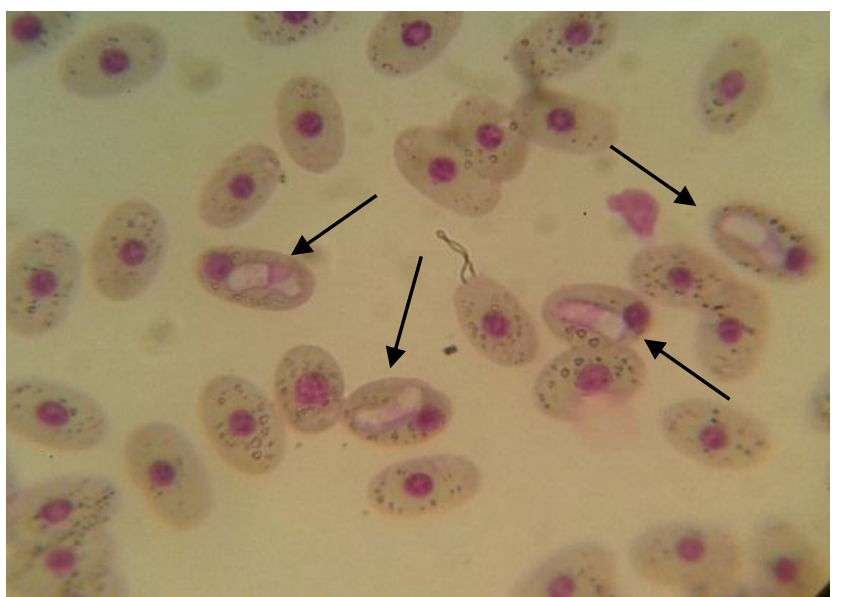

Figura 1. Eritrócitos de um cágado de barbicha (Phrynops geoffroanus) do estudo onde se observa a presença de hemoprotozoários (setas), salientando que esses animais foram negativos para os testes de PCR utilizados no estudo.

$\mathrm{Na}$ avaliação clínica e pesagem dos animais não foram observadas alterações de saúde para que os animais fossem considerados como doentes ou desnutridos, no entanto, em onze dos 99 cágados foram observadas a presença de sanguessugas. Sete desses animais foram positivos no exame direto para hemoparasitas e, nos exames moleculares foi detectada a presença de hemogregarina em cinco desses animais positivos e de Hepatozoon sp. em dois deles, sendo os demais foram negativos em todos os métodos diagnósticos utilizados no estudo.

Na maioria das amostras positivas era visível apenas um parasita por eritrócito (Figura 2), no entanto em alguns animais foi possível observar mais de um parasita por eritrócito (Figura 3). Os parasitas foram observados ocupando o comprimento longitudinal do eritrócito infectado, possuíam forma alongada e em algumas amostras observamos que deslocavam o núcleo do eritrócito. 


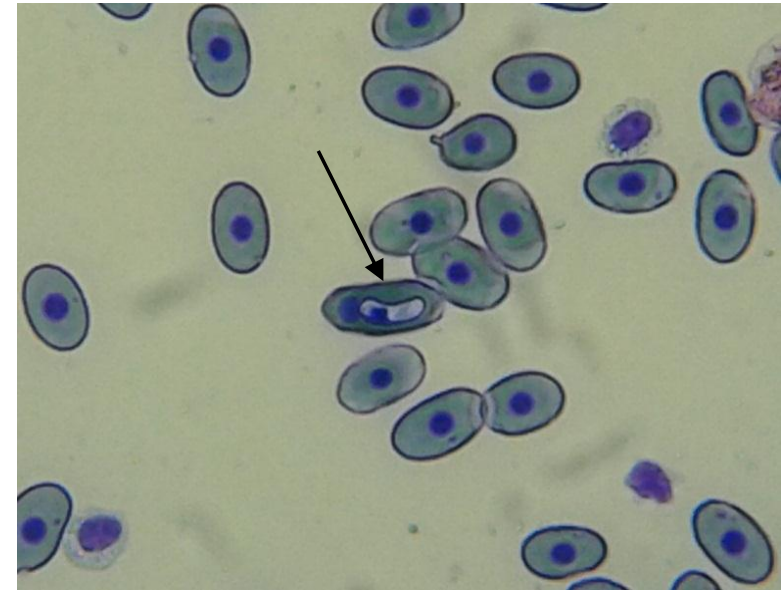

Figura 2. Eritrócito de tartaruga-da-Amazônia (Podocnemis expansa) com presença de um gametócito de hemoparasita (seta).

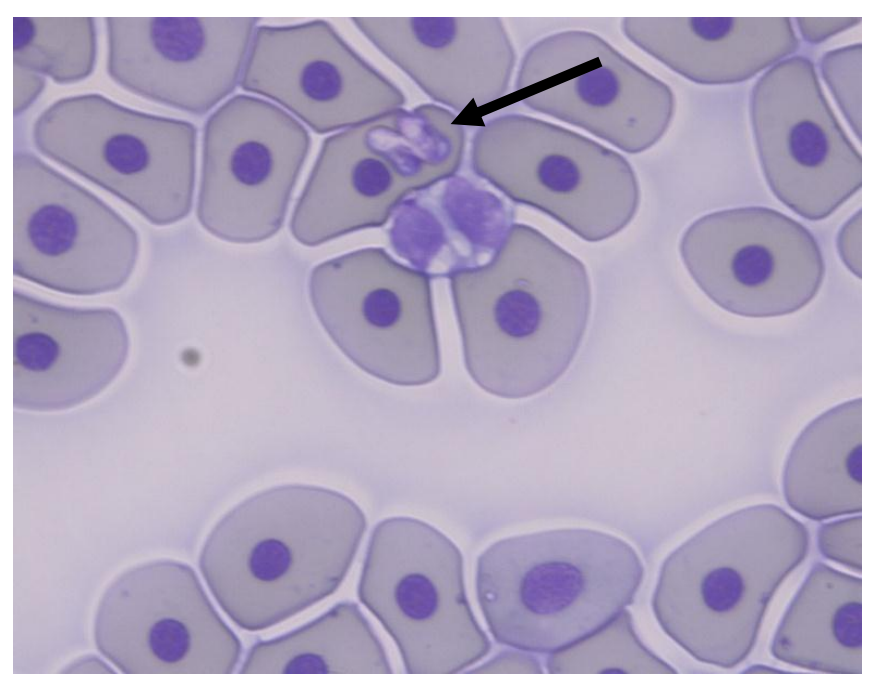

Figura 3. Eritrócito de P. expansa infectado por dois hemoparasitas no mesmo eritrócito (seta).

Nas amostras positivas obtidas pela PCR para hemogregarinas foi observado produto de 1000pb (Figura 4) e na PCR específica para o gênero Hepatozoon sp. as amostras positivas geraram produtos de aproximadamente 600 pb (Figura 5). 


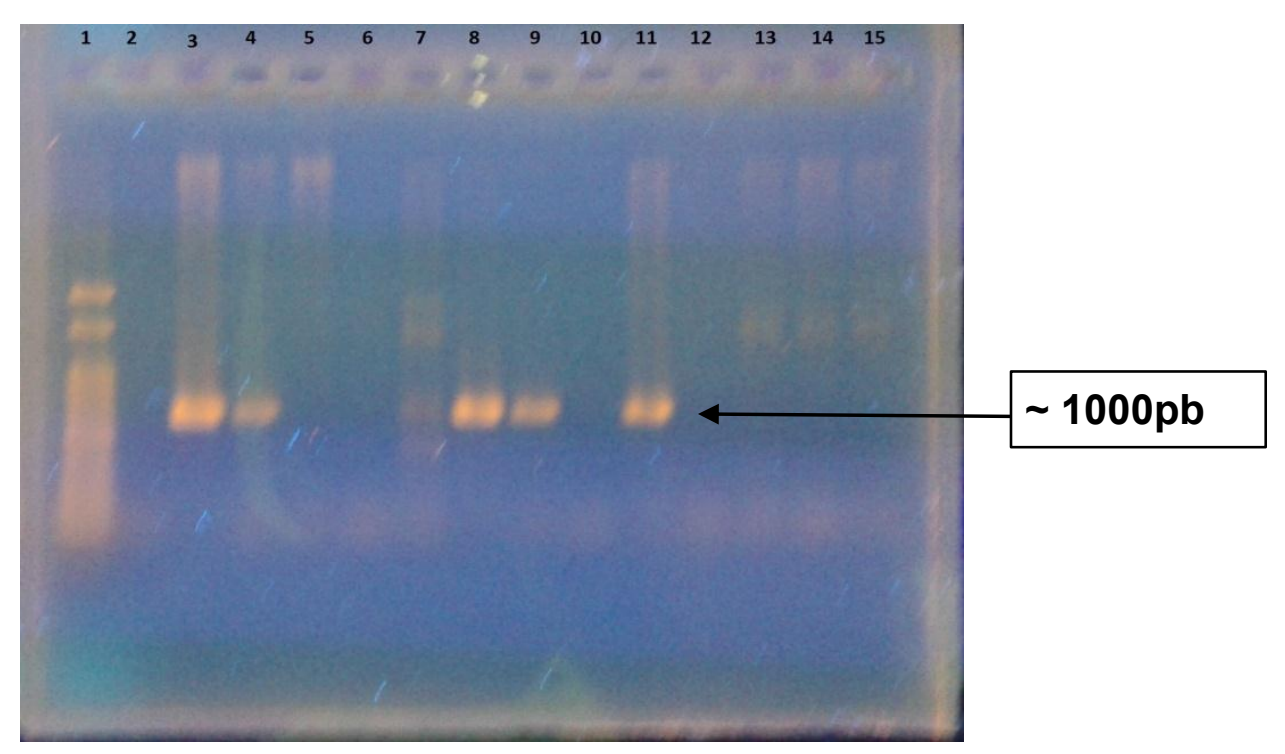

Figura 4. Resultado de PCR para detecção de hemoparasitos utilizando os oligonucleotídeos para detecção de hemograrinas. 1 - Marcador de peso molecular (100pb); 2 - controle negativo (água); 3 - controle positivo; 5, 6, 7, 10, 12,13, 14 e 15 - animais negativos ; 4,8,9 e 11 - animais positivos para o grupo das hemogregarinas. Gel de agarose a $1,5 \%(p / v)$ com brometo de etídeo a $0,01 \%(p / v)$.

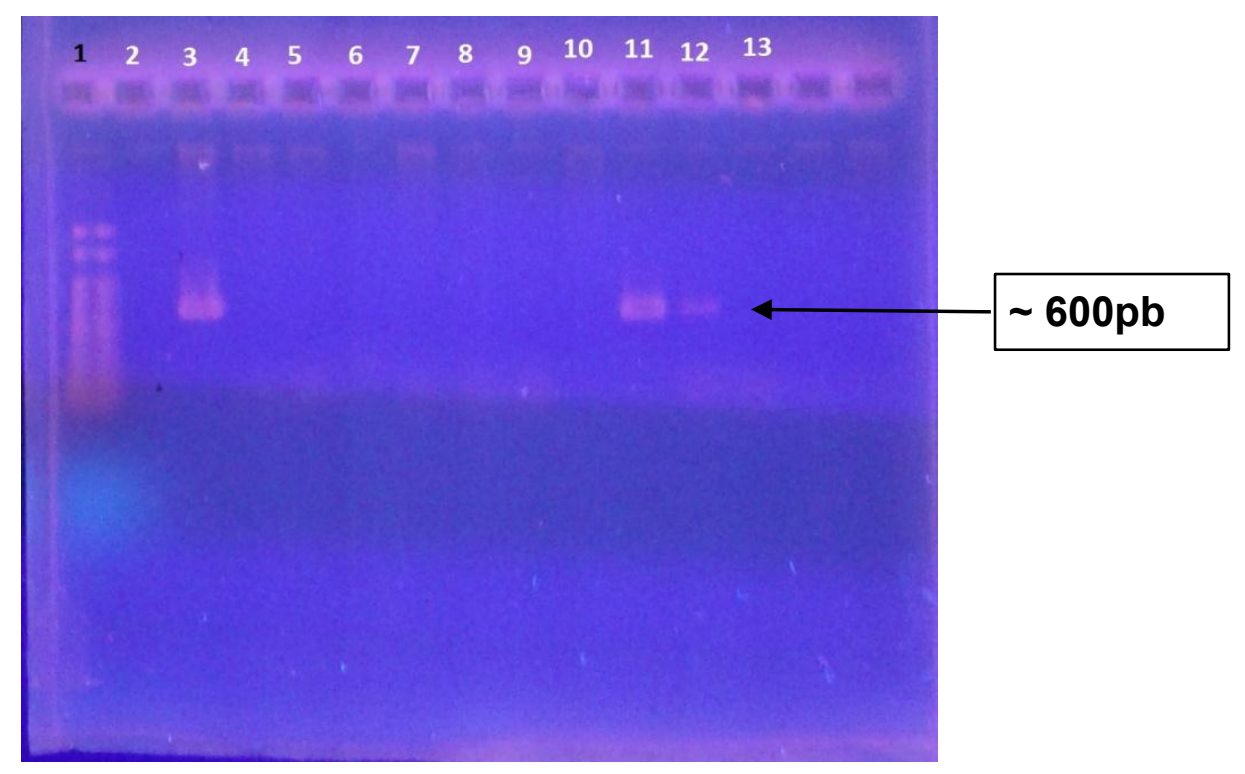

Figura 5. Resultado de PCR para detecção de hemoparasitos utilizando os oligonucleotídeos para detecção de Hepatozoon spp.: PCR "HEP", 1 - Marcador de peso molecular (100pb); 2 - controle negativo (água); 3 - controle positivo; 11 e 12 - animais positivos para Hepatozoon spp. ; 4,5,6,7,8,9,10 e 13 - animais negativos. Gel de agarose a $1,5 \%(p / v)$ com brometo de etídeo a $0,01 \%(p / v)$. 
A distribuição de animais infectados por hemoparasitas em cada método de diagnóstico utilizado de acordo com as espécies estudadas e sexo está relacionada na tabela 3.

Tabela 3. Número de animais positivos para hemoparasitas detectados em cada método de diagnóstico utilizado (Microscopia óptica - M.O. e PCR) distribuídas por espécie e sexo:

\begin{tabular}{c|c|c|c|c}
\hline Espécie & Sexo & M.O & "HEMO" & "HEP” \\
\hline \multirow{2}{*}{$\begin{array}{c}\text { Phrynops } \\
\text { geoffroanus }\end{array}$} & Macho & $22 / 34(64.7 \%)$ & $6 / 12(50 \%)$ & $2 / 2(100 \%)$ \\
& Indeterminado & $1 / 3(33.33 \%)$ & $6 / 12(50 \%)$ & \\
\hline $\begin{array}{c}\text { Podocnemis } \\
\text { expansa }\end{array}$ & Macho & $10 / 14(71.42 \%)$ & & \\
\hline
\end{tabular}

Nas infecções por hemogregarinas foram observadas diminuições $(p<0,05)$ nas concentrações das proteínas plasmáticas totais, das proteínas séricas totais, das globulinas e no número de trombócitos em ambas as espécies (Tabela 4). Nas infecções por Hepatozoon sp. foram observadas apenas aumento no número de trmbócitos (Tabela 5). 
Tabela 4. Valores médios e desvio padrão dos parâmetros hematológicos e bioquímicos dos animais positivos e negativos para infecção por hemogregarinas na PCR nas duas espécies estudadas $(n=99)$.

\begin{tabular}{|c|c|c|c|}
\hline \multirow{7}{*}{ 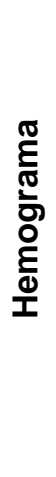 } & Parâmetros & Negativos (79/99) & $\begin{array}{l}\text { Positivos para hemogregarina } \\
(15 / 20)\end{array}$ \\
\hline & VG (\%) & $22.68( \pm 4,67)$ & $23,53( \pm 3,96)$ \\
\hline & Hemácias $\left(x 10^{6} \times \mu^{-1}\right)$ & $0,36( \pm 0,13)$ & $0,37( \pm 0,14)$ \\
\hline & Hemoglobina $(\mathrm{g} / \mathrm{dL})$ & $5,17( \pm 1,65)$ & $5,29( \pm 1,58)$ \\
\hline & Trombócitos $\left(\times 10^{3} \times \mu \mathrm{L}^{-1}\right)$ & $5,1( \pm 4,31)$ & $3,73( \pm 3,7)^{*}$ \\
\hline & PPT (g/dL) & $4,5( \pm 1,67)$ & $3,6( \pm 1,43)^{\star *}$ \\
\hline & Leucócitos $\left(\times 10^{3} \times \mu \mathrm{L}^{-1}\right)$ & $8,23( \pm 5,6)$ & $6,06( \pm 4,01)$ \\
\hline \multirow{11}{*}{$\begin{array}{l}\stackrel{0}{0} \\
\frac{0}{E} \\
\frac{\bar{g}}{\bar{J}} \\
\frac{0}{0}\end{array}$} & $\mathrm{FA}(\mathrm{UI} / \mathrm{L})$ & $11,9( \pm 64,9)$ & $131,06( \pm 105,47)$ \\
\hline & AST(UI/L) & $68,5( \pm 36,4)$ & $61,66( \pm 24,08)$ \\
\hline & Glicose (md/dL) & $70,01( \pm 51,5)$ & $57,53( \pm 21,11)$ \\
\hline & $\mathrm{Ca}(\mathrm{Meq} / \mathrm{L})$ & $11,37( \pm 3,68)$ & $11,18( \pm 4,32)$ \\
\hline & Uréia (mg/dL) & $16,46( \pm 18,03)$ & $24,8( \pm 27,57)$ \\
\hline & Proteína Total (g/dL) & $4,0( \pm 1,24)$ & $3,7( \pm 1,71)^{* \star *}$ \\
\hline & Albunina ( $g / d L)$ & $1,37( \pm 0,59)$ & $1,31( \pm 0,43)$ \\
\hline & Globulina (g/dL) & $2,5( \pm 1,02)$ & $2,1( \pm 1,29)^{* \star \star *}$ \\
\hline & Ácido úrico (mg/dL) & $2,5( \pm 5,9)$ & $1,55( \pm 1,3)$ \\
\hline & Fósforo (mg/dL) & $2,61( \pm 2,63)$ & $2,98( \pm 1,56)$ \\
\hline & CK (UI/L) & $1773( \pm 1752)$ & $1048,9( \pm 749,24)$ \\
\hline
\end{tabular}

Onde: ${ }^{*} \mathrm{p}=<0.05 ;{ }^{* \star} \mathrm{p}<0.01 ;{ }^{* \star *} \mathrm{p}<0.001 ;{ }^{* \star * *} \mathrm{p}<0.05$; Volume globular (VG); PPT (Proteínas Plasmáticas Totais); Aspartato aminotransferase (AST); Fosfatase alcalina (FA); Creatinina-quinase (CK) e Ca (Cálcio). 
Tabela 5. Valores médios e desvio padrão dos parâmetros hematológicos e bioquímicos dos animais positivos e negativos para infecção por Hepatozoon sp. na PCR nas duas espécies estudadas $(n=99)$.

\begin{tabular}{|c|c|c|c|}
\hline \multirow{7}{*}{ 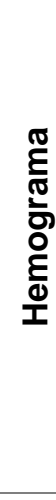 } & Parâmetros & Negativos (79/99) & $\begin{array}{c}\text { Positivos para Hepatozoon } \\
\text { sp.(9/20) }\end{array}$ \\
\hline & VG (\%) & $22.68( \pm 4,67)$ & $20,6( \pm 7,15)$ \\
\hline & Hemácias $\left(x 10^{6} \times \mu^{-1}\right)$ & $0,36( \pm 0,13)$ & $0,26( \pm 0,17)$ \\
\hline & Hemoglobina (g/dL) & $5,17( \pm 1,65)$ & $5,76( \pm 2,28)$ \\
\hline & Trombócitos $\left(\times 10^{3} \times \mu \mathrm{L}^{-1}\right)$ & $5,1( \pm 4,31)$ & $7,38( \pm 2,13)^{*}$ \\
\hline & PPT (g/dL) & $4,03( \pm 1,67)$ & $3,11( \pm 1,34)$ \\
\hline & Leucócitos $\left(\times 10^{3} \times \mu L^{-1}\right)$ & $8,23( \pm 5,6)$ & $4,5( \pm 2,57)$ \\
\hline \multirow{11}{*}{ 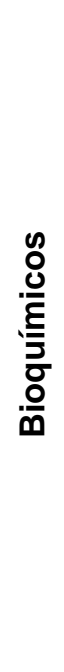 } & $\mathrm{FA}(\mathrm{UI} / \mathrm{L})$ & $11,9( \pm 64,9)$ & $63( \pm 20,05)$ \\
\hline & AST(UI/L) & $68,5( \pm 36,4)$ & $55,33( \pm 29,21)$ \\
\hline & Glicose (md/dL) & $70,01( \pm 51,5)$ & $46,22( \pm 13,94)$ \\
\hline & $\mathrm{Ca}(\mathrm{Meq} / \mathrm{L})$ & $11,37( \pm 3,68)$ & $11,22( \pm 5,26)$ \\
\hline & Uréia (mg/dL) & $16,46( \pm 18,03)$ & $33,22( \pm 47,37)$ \\
\hline & Proteína Total (g/dL) & $3,87( \pm 1,24)$ & $2,97( \pm 1,1)$ \\
\hline & Albunina $(\mathrm{g} / \mathrm{dL})$ & $1,37( \pm 0,59)$ & $1,16( \pm 0,45)$ \\
\hline & Globulina (g/dL) & $2,53( \pm 1,02)$ & $2,13( \pm 0,75)$ \\
\hline & Ácido úrico (mg/dL) & $2,5( \pm 5,9)$ & $2,92( \pm 1,06)$ \\
\hline & Fósforo (mg/dL) & $2,61( \pm 2,63)$ & *** \\
\hline & CK (UI/L) & $1773( \pm 1752)$ & $412,33( \pm 687,26)$ \\
\hline
\end{tabular}

Onde: ${ }^{*} \mathrm{p}<0.005 ;{ }^{* * *}=$ Valores não mensurados nos animais; Volume globular (VG); PPT (Proteínas Plasmáticas Totais); Aspartato aminotransferase (AST); Fosfatase alcalina (FA); Creatinina-quinase (CK) e Ca (Cálcio).

Quando analisadas as espécies separadamente, observou-se na espécie $P$. geoffroanus uma diminuição em relação a média nos parâmetros de proteínas plasmáticas, trombócitos e globulinas nos animais com a infecção por hemogregarinas, e nenhuma alteração foi observada para infecção com Hepatozoon $s p$. (Tabela 6). Na espécie $P$. expansa não foi observada nenhuma alteração nos parâmetros analisados. 
Tabela 6. Valores médios e desvio padrão dos parâmetros hematológicos e bioquímicos dos cágados positivos e negativos para a infecção por hemogregarinas na PCR na espécie Phrynops geoffroanus $(n=77)$.

Parâmetros

Negativos (64/77)

$\stackrel{0}{E}$
$\frac{\pi}{5}$
$\frac{0}{0}$
$\stackrel{0}{1}$
I

VG $(\%)$

Hemácias $\left(\times 10^{6} \times \mu^{-1}\right)$

Hemoglobina $(\mathrm{g} / \mathrm{dL})$

Trombócitos $\left(\times 10^{3} \times \mu \mathrm{L}^{-1}\right)$

$\frac{\text { PPT }(\mathrm{g} / \mathrm{dL})}{\text { Leucócitos }\left(\times 10^{3} \times \mu \mathrm{L}^{-1}\right)}$

$\begin{array}{ll} & 22,98 \\ & 0,39 \\ -1 & 5.08 \\ & 14,0 \\ & 3,\end{array}$

$22,98( \pm 4,17)$

$0,39( \pm 0,11)$

$5.08( \pm 1,32)$

$14,09( \pm 4,4)$

$3,14( \pm 1,66)$

$24( \pm 2,79)$

$0,43( \pm 0,12)$

$5,06( \pm 1,0)$

hemogregarinas $(12 / 77)$

$12,03( \pm 6,4)$ $2,23( \pm 0,86)$

$6,54( \pm 4,14)$

\begin{tabular}{|c|c|c|c|}
\hline \multirow{11}{*}{ 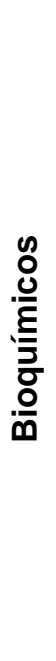 } & $\mathrm{FA}(\mathrm{UI} / \mathrm{L})$ & $125,7( \pm 64,23)$ & $148( \pm 111,59)$ \\
\hline & AST(UI/L) & $68,32( \pm 37,92)$ & $63,25( \pm 19,92)$ \\
\hline & Glicose (md/dL) & $76,56( \pm 54,21)$ & $61,66( \pm 20,37)$ \\
\hline & $\mathrm{Ca}(\mathrm{Meq} / \mathrm{L})$ & $11,55( \pm 3,36)$ & $11,22( \pm 3,03)$ \\
\hline & Uréia (mg/dL) & $14,75( \pm 16,7)$ & $22,58( \pm 14,5)$ \\
\hline & Proteína Total $(\mathrm{g} / \mathrm{dL})$ & $4,05( \pm 1,23)$ & $4,75( \pm 1,67)$ \\
\hline & Albunina (g/dL) & $1,34( \pm 0,53)$ & $1,29( \pm 0,44)$ \\
\hline & Globulina (g/dL) & $2,76( \pm 0,85)$ & $2,36( \pm 1,24)^{* *}$ \\
\hline & Ácido úrico $(\mathrm{mg} / \mathrm{dL})$ & $2,4( \pm 7,2)$ & $1( \pm 0,6)$ \\
\hline & Fósforo (mg/dL) & $3,25( \pm 2,71)$ & $3,23( \pm 1,36)$ \\
\hline & CK (UI/L) & $1790,1( \pm 1737,2)$ & $1244,4( \pm 685,95)$ \\
\hline
\end{tabular}

Onde: Valores em uma mesma linha seguidos por letras diferentes diferiram $(p<0,05)$ no teste de modelo linear. ${ }^{*} p<0.005 ;{ }^{* *} p<0.001 ;{ }^{* * *} p<0.05$; Volume globular (VG); PPT (Proteínas Plasmáticas Totais); Aspartato aminotransferase (AST); Fosfatase alcalina (FA); Creatinina-quinase (CK) e Ca (Cálcio). 


\section{DISCUSSÃO}

O presente estudo mostrou que existe uma elevada ocorrência de infecção por hemogregarinas nos cágados mantidos na Fundação Zoológico de Brasília, pois foram encontradas amostras positivas tanto na PCR quanto no exame direto. Salientando que a ocorrência hemogregarina pelo exame direto foi muito superior ao encontrado para os exames moleculares, o que faz sugerir que outra espécie de hemoparasita esteja infectando as espécies de cágados e com uma alta prevalência na população amostrada. Confirmando assim o que afirmou Harris et al., 2011 que os níveis de infecção relatados de estudos utilizando diferentes oligonucleotídeos devem, portanto, ser comparados com cautela.

Outros estudos também revelaram uma alta prevalência de hemoparasitas em cágados (SIDDALL; DESSER 1992; MCALLISTER et al. 1995; JAKES et al. 2001; MIHALCA et al., 2002, MOLLA et al., 2013; JAVANBAKHT; SHARIFI, 2014), tendo alguns obtidos uma prevalência de até $100 \%$ nas populações estudadas em várias regiões geográficas, como nos Estados Unidos (McALLISTER; KING, 1980), no Canadá (SIDDALL; DESSER, 1992), na Romênia (MIHALCA et al.,2002), na Austrália (JAKES et al.,2001; PIERCE; ADLARD, 2004), corroborando com o estudo em questão que encontrou uma alta prevalência da infecção por hemoparasitas nos cágados estudados.

Importante observar que foram observadas sanguessugas em apenas 11 animais, sendo todos da espécie $P$. Expansa. Apesar de serem considerados os principais vetores de hemogregarinas em cágados (SIDDALL;DESSER, 2001, TELFORD, 2008), apenas sete destes animais foram positivos nos testes de PCR para infecção por hemogregarinas e/ou Hepatozoon sp. Há registros de sanguessugas como vetores invertebrados de hemogregarinas do gênero 
Haemogregarina (DESSER, 1993; SIDDALL, 1995; DESSER; SIDDALL, 2001), corroborando com os achados do nosso estudo. As $P$. expansa, por serem animais aquáticos e de grande porte, tendem a passar muito tempo na água e com isso são mais propensos ao parasitismo por sanguessugas (RYAN:LAMBERT,2005; McCOY et al.,2007; READEL et al.,2008; DAVIS;STERRETT, 2011), lembrando que não podemos descartar a possibilidade dos demais animais positivos terem sido infectados também através de sanguessugas, pois convivem em um ambiente propício para a presença, bem como por mosquitos que também são considerados os vetores de hemoparasitas em répteis (TELFORD, 2008).

Os parasitas observados na microscopia óptica apresentavam características morfológicas similares as hemogregarinas descritas por TELFORD Jr., 2000 e THRALL et al.,2007. No entanto, a precisão na identificação só é possível com a combinação da descrição dos estágios esporogonia no vetor (DESSER et al., 1995), no presente estudo não foi realizada a observação do ciclo biológigo, impossibilitando esta classificação.

Em parasitas do sub-filo Apicomplexa, os gametócitos estão comumente individualizados dentro de uma única célula, na circulação do hospedeiro, como por exemplo, eritrócitos; no entanto duas ou três formas podem ser observadas (JOVANI et al. 2004). O termo double gametocyte, foi utilizado por Jovani (2002) para explicar infecções com gametócitos duplos (DGl'S). A ocorrência de DGl'S é frequente em eritrócitos de répteis, como quelônios (MIHALCA et al., 2002; SIROKY et al. 2004). As amostras estudadas apresentaram animais com parasitismo duplo. Segundo Jovani (2002), a ocorrência de dois ou mais gametócitos presentes em uma única célula é considerada como potencial para facilitar a transmissão do parasito para hospedeiros invertebrados. 
A notável dificuldade de identificar as diferenças morfológicas, combinada com o desenvolvimento de oligonucleotideos universais, fazem com que mais avaliações de infecções por hematozoários sejam realizadas utilizando ferramentas moleculares e, em particular, o sequenciamento do gene de 18S rRNA para hemogregarinas (CRIADO- FORNELIO et al., 2009; MERINO et al., 2009; VILCINS et al., 2009; DVOŘÁKOVÁ et al, 2015). Importante salientar que Criado-Fornelio et al. (2007, 2009) relataram a descoberta de resultados não positivos ao examinar esfregaços de sangue, mas obtiveram resultados positivos através de PCR e metodologias de seqüenciamento de DNA, o que foi observado no presente estudo, onde três animais foram positivos na PCR e negativos na microscopia óptica.

No presente estudo, observou-se uma diferença significativa na sensibilidade de detecção entre as duas metodologias, sendo observada uma maior ocorrência de animais positivos na microscopia óptica em relação a PCR. Isto pode ter ocorrido devido aos conjuntos de oligonucleotídeos utilizados serem específicos apenas o gene 18S rRNA das hemogregarinas, não conseguindo amplificar os genes de outros hemoparasitas presentes nas amostras, tais resultados foram similares aos encontrados por Moço et al. (2011) que conduziram estudos moleculares com Hepatozoon sp. de C. durissus terrificus utilizando os oligonucleotídeos que amplificaram regiões do gene $18 \mathrm{~S}$ rRNA e não conseguiram detectar todos os hemoparasitas que infectavam os animais estudados. Enquanto no estudo de Moço (2012) foram testados outros oligonucleotídeos, que amplificaram a região ITS-1, ITS-1, 5.8S e ITS-2 e outros que amplificaram regiões do gene $18 \mathrm{~S}$ rRNA, conseguiram sequências que indentificaram um maior número de espécies de hemoparasitas. Assim, provavelmente, se tivéssemos utilizado associações de outros oligonucleotídeos, poderíamos ter obtido uma maior ocorrência de 
hemogregarinas identificadas pelos testes moleculares. Ainda ressaltamos a presença de quatro animais positivos apenas para PCR do Hepatozoon sp., o que sugere que possa existir diferenças gênicas no sítio de anelamento dos oligonucleotídeos para hemogregarinas, corroborando a necessidade de estudos futuros utilizando outros conjuntos de oligonucleotídeos.

Os animais silvestres tendem a manifestar poucos sinais reconhecíveis de doenças, sendo os exames laboratoriais considerados como ferramentas para diagnosticar e prevenir doenças e até mesmo como bioindicadores de agressões ambientais (ALMOSNY; MONTEIRO, 2007). No pesente estudo não foram obsevadas alterações clínicas nos animais. Nas análises laboratoriais de hemograma e bioquímica, como não tinhamos padrão hematológico como referência para as espécies estudadas, foram utilizados animais negativos para hemogregarina na PCR como a referência. Assim, comparamos os exames realizados com os resultados dos animais positivos nos exames moleculares, sendo encontrado diferenças nos animais positivos para hemogregarinas para os parâmetros de proteínas plasmáticas totais, trombócitos, proteínas séricas totais e globulinas; já para os positivos para Hepatozoon sp. obtivemos alterações apenas no parâmetro dos trombócitos para ambas as espécies. Quando comparadas as espécies separadamente observamos alterações nos exames para a espécie $P$. geoffroanus nos animais positivos no teste molecular para hemogregarinas. Nos animais positivos para hemogregarinas, obteve-se uma mensuração de proteínas plasmáticas totais, proteínas séricas totais e globulinas abaixo dos valores médios observados nos animais negativos. Sabendo que os níveis de proteínas nos animais depende do manejo, dietas e variações fisiológicas normais de cada espécie (SANTOS et al., 2005), e que a hipoproteinemia é comumente observada em répteis 
com desnutrição crônica e parasitismo gastrointestinal (DEEM et al., 2009). Outras causas, no entanto, tais como má absorção, má digestão, enteropatia perdedora de proteínas, perda grave de sangue, e doença hepática ou doença renal crônica, devem também ser considerados (CAMPBELL, 2014). Porém no presente estudo estas possibilidades podem ser descartadas uma vez que não foram observadas alterações nos exames bioquímicos destes órgãos. Logo sugere-se que a causa desse baixo nível na mensuração das proteínas pode estar diretamente ligada a presença dos hemoparasitas, pois com a infecção os animais acabam se alimentando menos que os negativos, causando uma desnutrição, ou mesmo a presença concomitante de parasitas gastrointestinais, pois no estudo não avaliamos esse nível de parasitismo. Os trombócitos nos répteis possuem como função principal participar da coagulação sanguínea e alguns estudos demonstram que também possuem capacidade fagocitária (ALMOSNY, SANTOS, 2002). Trombocitopenia em répteis geralmente é resultado de excessiva utilização ou deficiente produção de trombóticos (HAWKEY;DENNET, 1989). Assim, a trombocitopenia observada nos animais positivos para hemogregarinas no estudo pode sugerir que a presença de parasitas desse grupo pode causar uma trombocitopenia que pode estar associada a uma produção deficiente dos trombócitos ou mesmo um consumo maior destas células sanguíneas quando há presença de hemoparasitose. Já o aumento dos trombócitos observados nos animais positivos para Hepatozoon spp. pode sugerir que a infecção por este parasita causa um aumento desses trombócitos sem alteração de nenhum outro parâmetro avaliado o que pode estar relacionada a defesa do animal, já que os trombócitos também possuem atividade fagocitária. Nenhuma alteração foi observada nos exames das $P$. expansa para os testes moleculares realizados, 0 
que pode ter ocorrido devido ao número reduzido de animais desta espécie analisados no estudo com poucas amostras positivas. 


\section{CONCLUSÃO}

A pesquisa realizada com as espécies $P$. expansa e $P$. geoffroanus revelou ocorrência de infecção por hemogregarinas por meio da PCR em 20,21\% das amostras analisadas, similar o que a literatura menciona sobre uma prevalência e intesidade alta de infecção de cágados por hemoparasitas. Na microscopia óptica pode-se observar uma ocorrência maior de infecção que nas análises moleculares, o que denota a possibilidade de existência de outras espécies de hemoparasitas infectando esses cágados que não foram possíveis de serem identificados pelos oligonucleotídeos utilizados no estudo. Foram observadas alterações laboratoriais apenas nos parâmetros de proteínas plamáticas totais, trombócitos, proteínas séricas totais e globulinas na infecção por hemogregarinas, e nos trombócitos na infecção por Hepatozoon sp. em ambas as espécies, enquanto que na avaliação de espécies em separados observou-se uma alteração nos parâmetros de trombócitos, proteínas plasmáticas totais e globulinas na infecção por hemogregarina na espécie P. geoffroanus. Assim, estudos subsequentes, utilizando marcadores moleculares adicionais, deverão ser realizados para identificar esses parasitas e avaliar mais precisamente os efeitos que estes parasitismos podem causar na saúde das espécies de cágados da instituição. 


\section{REFERÊNCIAS BIBLIOGRÁFICAS}

1. Almosny N.R.P. \& Monteiro A.O. 2007. Patologia Clínica. In: CUBAS, Z. S.; SILVA, J.C.R.; CATÃO DIAS, J.L. Tratado de Animais Selvagens. São Paulo: Roca, Cap 59, p939-966.

2. Almosny N.R.P. \& Santos L. C. 2002. Laboratory Support in Wild Animal Medicine. In: Biology, Medicine and surgery of south american wild animals. lowa State University Press. p.500-503.

3. Amo L., Lopez P. \& Martin J. 2004. Prevalence and intensity of haemogregarinid blood parasites in a population of the Iberian rock lizard, Lacerta monticola. Parasitology Research. 94:290-293.

4. Ball G.H. 1997. Some Blood Sporozoans from East African Reptiles. The Journal of Eukaryotic Microbiology, Lawrence, US, v. 14, n. 2, p. 198-210.

5. Campbell T.W. 1996. Hemoparasites. In: Mader D.R. Reptile Medicine and Surgery. Philadelphia: W.B. Saunders, 1996. p. 379-381.

6. Campbell T.W. 2014. Clinical pathology. In: Mader, D.R. (Ed.), Reptile Medicine and Surgery. W.B. Saunders Co., Philadelphia, U.S.A.

7. Campos Brites V.L. \& Rantin F.T.2004. The influence of agricultural and urban contamination on leech infestation of freshwater turtles, Phrynops geoffroanus, taken from two areas of the Uberabinha River. Environmental $\begin{array}{llll}\text { Monitoring and } & \text { Assessment. }\end{array}$ http://dx.doi.org/10.1023/B:EMAS.0000031733.98410.3c. PMid:15327164

8. Caudell J.N., Whittier J. \& Conover M.R. 2002. The effects of haemogregarine- like parasites on brown tree snakes (Boiga irregularis) and slatey-grey snakes (Stegonotus cucullatus) in Queensland, Australia. International Biodeterioration \& Biodegradation. 49: 113-9. 
9. Criado-Fornelio A., Buling A., Casado N., Gimenez C., Ruas J., Wendt L., Da Rosa-Freitas N., Pinheiro M., Rey-Valeiron C. \& Barba-Carretero J.C. 2009. Molecular characterization of arthropod-borne hematozoans in wild mammals from Brazil,Venezuela and Spain. Acta Parasitologica 54: 187-193.

10. Criado-Fornelio A., Ruas J.L., Casado N., Farias N.A.R., Soares M.O., Muller G., Brum J.G.W., Berne M.E.A., Buling-Sarana A. \& BarbaCarretero J.C. 2007. New molecular data mammalian Hepatozoon species (Apicomplexa: adeleorina) from Brazil and Spain. Journal of Parasitology. 92: 93-99.

11. Davis A.K. \& Sterrett S.C. 2011. Prevalence of Haemogregarine parasites in three freshwater turtle species in a population in Northeast Georgia, USA. International journal of zoological Research. 7(2):156-163.

12.Deem S.L., Norton T.M., Mitchell M., Segars A., Alleman A.R., Cray C., Poppenga R.H., Dodd M. \& Karesh W. B. 2009. Comparison of blood values in foraging, nesting, and stranded Loggerhead turtles (Caretta caretta) along the coast of Georgia, USA. Journal Wildlife Disease. 45:41-56.

13. Desser S.S. 1993. The Haemogregarinidae and Lankesterellidae. In: Kreier, J.P. (ed.). Parasitic Protozoa, New York: Academic Press, p. 247-272.

14. Desser S.S., Hong H. \& Martin D.S. 1995. The life history, ultrastructure, and experimental transmission of Hepatozoon catesbianae N. Comb., an apicomplexan parasite of the Bullfrog, Rana catesbeiana and the mosquito, Culex territans in Algonquin Park, Ontario. Journal of Parasitoology. v. 81, p. 212-222.

15.Dvořáková N., Kvičerová J., Hostovský M. \& Široký P. 2015. Haemogregarines of freshwater turtles from Southeast Asia with a description 
of Haemogregarina sacaliae sp. n. and a redescription of Haemogregarina pellegrini Laveran and Pettit, 1910. Parasitology. 142:816-826.

16. Garcia-Navarro C.E.K., Pachaly, J.R. 1994. Manual de hematologia veterinária. São Paulo: Livraria Varela. 169p.

17. Harris D.J., Maia J.P.M.C. \& Perera A. 2011. Molecular Characterization of Hepatozoon species in reptiles fron the Seychelles. Journal of Parasitology. 97(1):106-10.

18. Hawkey C.M. \& Dennet T.B.1989. Comparative veterinary haematology. Ipswich : W.S. Cowell. 192p.

19. Inokuma H, Okuda M, Ohno K, Shimoda K \& Onishi T. Analysis of the $18 \mathrm{~S}$ rRNA gene sequence of a Hepatozoon detected in two Japanese dogs. Veterinary Parasitology.106(3): 265-71.

20. Jakes K.A., Donoghue P.O., Munro M. \& Adlard R. 2001. Hemoprotozoa of freshwater turtles in queensland. Journal of Wildlife Diseases. 37:12-19.

21. Javanbakht H. \& Sharifi M. 2014. Prevalence and intensity of Haemogregarina stepanowi (Apicomplexa: Haemogregarinidae) in two species of freshwater turtles (Mauremys caspica and Emys orbicularis) in Iran. Journal of Entomology and Zoology Studies. 2 (4): 155-158.

22. Jovani R. 2002. Malaria transmission, sex ratio, and erythrocytes with two gametocytes. Trends parasitology. 18: 537-539.

23. Jovani R., Amo L., Arriero E., Krone O., Marzal A., Shurulinkov P., Tomás G., Sol D., Hagen J., Lopez P., Martin J., Navarro C. \& Torres J. 2004. Double gametocyte infections in apicomplexan parasites of birds and reptiles. Parasitol Res. 94: 155-157. 
24. Lainson R. \& Naiff R. 1998. Haemoproteus (Apicomplexa: Haemoproteidae) of tortoises and turtles. Proceedings of the Royal Society B. 265:941-949.

25. Levine N.D., Corliss J.O., Cox F.E.G., Deroux G., Grain J., Honigberg B.M., Leedale G.F., Loeblich A.R., Lom J., Lynn D., Merinfeld E.G., Page F.C., Poljandky G., Sprague V., Vavra J. \& Wallace F.G. 1980. A newlyrevised classification of the Protozoa. Journal of Protozoology. 27:37-58.

26. Majláthová V., Majláth I., Haklová B., Hromada M., Ekner A., Antczak M. \& Tryjanowski P. 2010. Blood parasites in two co-existing species of lizards (Zootoca vivipara and Lacerta agilis). Parasitology Research. 107:1121-1127.

27. Martin J., Amo L. \& López P. 2008. Parasites and health affect multiple sexual signals in male common wall lizards, Podarcis muralis. Naturwissenschaften 95:293-300.

28. Martinez-Silvestre A., Perpiñán D., Marco I. \& Lavin S. 2002. Venipuncture Technique of the Occipital Venous Sinus in Freshwater Aquatic turtles. Journal of Herpetological Medicine and Surgery. 12(4):31-32.

29. McAllister C.T. \& King A.W. 1980. Hemogregarines in the red-eared slider, Chrysemys scripta elegans (Wied) from Arkansas. Proceedings of Arkansas Academy of Science. 34:124

30.McAllister C.T., Upton S.J. \& Trauth S.E. 1995. Hemogregarines (Apicomplexa) and Falcaustra chelydrae (Nematoda) in an alligator sapping turtle, Macroclemys temminckii (Reptilia: Testudinidae), from Arkansas. Journal of The Helminthological Society of Washington. 62:74-75.

31.McCoy J.C., Failey E.L., Price S.J. \& Dorcas M.E. 2007. An assessment of leech parasitism on semi-aquatic turtles in the Western Piedmont of North Carolina. Southeastern Naturalist. 6: 191-202. 
32. Merino S., Vasquez R.A., Martinez J., Celis-Diez J.L., Gutierrezjimenez L., Ippi S, Sanchez-Monsalvez I. \& La Puente J.M. 2009. Molecular characterization of an ancient Hepatozoon species parasitizing the 'living fossil' marsupial 'Monito del Monte' Dromiciops gliroides from Chile. Biological Journal of the Linnean Society. 98: 568-576.

33. Mihalca A.D., Achelaripei D. \& Popescu P. 2002. Haemoparasites to the genus Haemogregarina in a populaion of European pond turtles (Emys orbicularis) from Dragasani, Valcea country, Romania. Revista Scientia Parasitologica. 3: 22-7.

34. Mihalca A.D., Racka K., Gherman C. \& Ionescu D.T. 2008. Prevalence and intensity of blood apicomplexan infections in reptiles from Romania. Parasitology Research. 102:1081-1083.

35. Minchella D.J. 1985. Host life-history variation in response to parasitism. Parasitology. 90:205-216.

36. Moço T.C. 2012. Caracterização morfológica, morfométrica e molecular de Hepatozoon spp. (Apicomplexa, Hepatozoidae) de serpentes brasileiras naturalmente infectadas. Tese (Doutorado) - Universidade Estadual Paulista, Faculdade de Ciências Biológicas de Botucatu.

37. Moço T.C., Silva R.J., Madeira N.G., Paduan K.S., Rubini A.S., Leal D.D.M. \& O'dwyer L.H. 2011. Morphological, morphometric and molecular characterization of Hepatozoon spp. (Apicomplexa, Hepatozoidae) from naturally infected Caudisona durissa terrifica. Parasitology Research. 110(4):1393-401. 
38. Molla S.H., Bandyopadhyay P.K. \& Gürelli G. 2013. On the Occurrence of a Haemogregarinae (Apicomplexa) Parasite from freshwater Turtles of South 24 Parganas, West Bengal, India. Turkiye Parazitolojii Dergisi. 37:118- 22.

39. Møller A.P. 1997. Parasitism and the evolution of host life history. In: Clayton D.H., Moore J. (eds) Host-parasite evolution: general principles and avian models. Oxford University Press, Oxford, pp 105-127.

40. Mundim A.V., Mundim M.J.S. \& Santos A.L.Q. 1994. Ocorrência de hemoparasitas em tartaruga da Amazônia (Podocnemis expansa) (Testudinata: Pelomedusidae). Revista do Centro de Ciências Biomedicas da Universidade Federal de Uberlândia. 10:111-113.

41. O’dwyer L.H., Moço T.C., Barella T.H., Vilela, F.C. \& Silva R.J. 2003. Prevalence of Hepatozoon spp. (Apicomplexa, Hepatozoidae) among recently captured Brazilian snakes. Arquivo Brasileiro de Medicina Veterinária e Zootecnia. 55:309-314.

42. Olsson M., Wapstra E., Madsen T., Ujvari B. \& Rugfelt C. 2005. Costly parasite resistance: a genotype-dependent handicap in sand lizards? Biology Letters. 1:375-377

43. Oppliger A. \& Clobert J. 1997. Reduced tail regeneration in the common lizard, Lacerta vivipara, parasited by blood parasites. Functionsl Ecology. $11: 652-655$.

44. Perkins S.L. \& Keller A.K. 2001. Phylogeny of nuclear small subunit rRNA genes of hemogregarines amplified with specific primers. Journal of Parasitology 87:870-876.

45.Pessoa S.B. \& Cavalheiro J. 1969a. Notas sobre Hemogregarinas de serpents brasileiras. VII Revista Brasileira de Biologia 29: 351-354. 
46.Pessoa S.B. \& Cavalheiro J. $1969^{\mathrm{b}}$.Notas sobre Hemogragarinas de serpentes Brasileiras. VIII. Sobre a evolução da "Haemogregarina miliaris" na sanguessuga "Haementeria lutzi". Revista Brasilaiera de Biologia 29: 351-354.

47. Picelli A. M., Carvalho A. V., Viana Al. A. \& Malvasio. 2015. Prevalence and parasitemia of Haemogregarina sp. in Podocnemis expansa (Testudines: Podocnemididae) from the Brazilian Amazon. Brazilian Journal of Veterinary Parasitology. Jaboticabal, 24(2):191-197.

48. Pierce M.A. \& Adlard R.D. 2004. Haemoparasites from clinical screening of reptiles in south-east Queensland, Australia. The Veterinary Record. 155, 708709.

49. Readel A.M., Phillips C.A. \& Wetzel M.J. 2008. Leech parasitism in a turtle assemblage: Effects of hosts and environmental characteristics. Copeia, 1: 227-233.

50. Ryan T.J. \& Lambert A. 2005. Prevalence and colonization of Plocobdella on two species of freshwater turtles (Graptemys geographica and Sternotherus odoratus). Journal of Herpetology. 39:284-287.

51.Santos A.L.Q., Malta T.S., Mundim A.V., Alves Júnior J.R.F. \& Carvalho S.F.M.2005. Variação dos constituintes bioquímicos sanguíneos de tartarugas-da-Amazônia (Podocnemis expansa, Schweigger 1812) (Testudinata) mantidas em criatório comercial. Archives of Veterinary Science.10 (3):1-8.

52.Sheldon B.C. \& Verhulst S. 1996. Ecological inmunology: costly parasite defences and trade-offs in evolutionary ecology. Trends in Ecology \& Evolution. 11: 317-21. 
53.Siddall M.E. \& Desser S.S. 1991. Merogonic development of Haemogregarina balli (Apicomplexa : Adeleina : Haemogregarinidae) in the leech Placobdella ornata (Glossiphoniidae), its transmission to a chelonian intermediate host and phylogenetic implications. Journal of Parasitology. $77: 426-436$.

54.Siddall M.E. \& Desser S.S. 1992. Prevalence and intensity of Haemogregarina balli (Apicomplexa, Adeleina, Haemogregarinidae) in three turtle species from ontario, with observations on intraerythrocytic development. Canadian Journal of Zoology. 70: 123-8.

55. Siddall M.E. \& Desser S.S. 1993. Ultrastructure of merogonic development of Haemogregarina (sensu lato) myoxocephali (Apicomplexa: Adeleina) in the marine leech Malmiana scorpii and localization of infective stages in the salivary cells. European Journal of Protistology. 29:191-201.

56. Siddall M.E. \& Desser S.S. 2001. Transmission of Haemogregarina balli from painted turtles to snapping turtles through the leech Placobdella ornata. Journal of Parasitology. 87:1217-8.

57.Siddall M.E. 1995. Phylogeny of Adeleid blood parasites with a partial systematic revision of the haemogregarine complex. The Journal of Eukaryotic Microbioogyl. 24:1161-125.

58.Siroky P., Kamler M. \& Modry D. 2004. Long-term occurrence of Hemolivia cf. mauritanica (Apicomplexa: Adeleina: Haemogregarinidae) in captive Testudo marginata (Reptilia: Testudinidae): evidence for cyclic merogony? Journal of Parasitology. 90: 1391-1393.

59.Smith, T. G. 1996. The genus Hepatozoon (Apicomplexa: Adeleina). Journal of Parasitology. 82, 565-585 
60.Soares P., De Brito E.S., Paiva F., Pavan D. \& Viana L.A. 2014. Haemogregarina spp. in a wild population from Podocnemis unifilis Troschel, 1848 in the Brazilian Amazonia. Parasitology Research. 113:4499-4503. doi: $10.1007 / \mathrm{s} 00436-014-4139-7$

61.Sorci G. 1996. Patterns of haemogregarine load, aggregation and prevalence as a function of host age in the lizard Lacerta vivipara. Journal of Parasitology. 82:676-678.

62. Telford Jr S.R. 2000. Diagnosis of Reptilian Protozoal Infections, p.243-257. In: Fudge AM (Ed.) Laboratory Medicine Avian and Exotic pets. WB. Sauders, Philadelphia.

63. Telford S.R. 2009. Hemoparasites of the Reptilia: Color Atlas and Text. CRC Press, Taylor and Francis Group, Boca Raton, Florida.

64.Thrall M.A., Baker D.C., Campbell T.W., De Nicola D., Fettman M.J., Lassen E.D., Rebar A. \& Weiser G. 2007. Hematologia e Bioquímica Clínica Veterinária. Roca, São Paulo, p.259-260.

65. Vilcins I. E., Ujvari B., Old J. M. \& Deane E. 2009. Molecular and morphological description of a Hepatozoon species in reptiles and their ticks in the Northern territory, Australia. Journal of Parasitology. 95: 434-442.

66.Wosniak E.J., Mclaughlin G.L. \& Telford S.R.1994. Description of the vertebrate stages of a hemogregarine species naturally infecting Mojave Desert Sidewinders (Crotalus cerastes cerastes). Journal of Zoo and Wildlife Medicine.25(1): 103-110. 